Jorge Salmerón-Castro 1 Eduardo César Lazcano Ponce 2 Ricardo Pérez Cuevas 1 Iliana del Río Gómez 2 I rene Torres Torija 3 Mauricio Hernández Avila 2

\section{Proposal to institutionalize criteria and quality standards for cervical cancer screening within a health care system}

\author{
Proposta de regulamentação de critérios \\ e padrões de qualidade para rastreamento \\ de câncer de colo uterino em um sistema \\ de atenção à saúde
}

1 Unidad de Investigación Epidemi ológi ca y en Servicios de Salud, Centro Médico Nacional Si gl o XXI, Instituto Mexicano del Seguro Social. Av. Cuahutemoc 330, Unidad deCongresos $B$ loque $B$, 4o piso, México, D. F. C. P. 06720,México.

2 Centro de Investigaciones en Salud Poblacional, Insti tuto Nacional de Salud Pública. Av. Universidad 655 Col. Sta. Ma. Ahuacatitlán. C. P. 62508. Cuernavaca, Morel os,México.

3 Jefatura de Enseñanza, Delegación Morelos, Centro Médico Nacional Sigl o XXI, Instituto Mexicano del Seguro Social. Av. Cuahutemoc 330 Unidad de Congresos BloqueB, 4o piso, México, D. F. 06720,M éxico.
Abstract The uterine cervix is the most common cancer site for females. Approximatel y 52,000 new cases occur annually in Latin America, thus the need to improve effici ency and effectiveness of Cervical Cancer Screening Programs (CCSP) is mandatory to decrease the unnecessary suffering women must bear. This paper is addressing essential issues to revamp the CCSP as proposed by the Mexican official norm. A general framework for institutionaling CCSP is outlined. Furthermore, strategies to strengthen CCSP performance through managerial strategies and quality assurance activities are described. The focus is on the foll owing activities: 1) improving coverage; 2) implementing smear-taking qual ity control; 3) improving quality in interpretati on of Pap test; 4) guaranteeing treatment for women for whom abnormaliti es are detected; 5) improving follow-up; 6) development of quality control measures and 7) development of monitoring and epidemiological surveil lance information systems. Changes within the screening on cervical cancer may be advocated as new technologies present themselves and shortcomings in the existing program appear. It is crucial that these changes should be measured through careful eval uation in order to tally up potential benefits.

Key words Cervix Neoplasms; Diagnosis; Papillomavirus; Quality Control

Resumo O colo uterino éa localização tumoral mais importante em mulheres na América Latina, ocorrendo aproximadamente 52 mil novos casos anualmentena região. Assi m, a necessi dade de mel horar a efi ciência e efeti vidade dos programas de rastreamento de câncer de colo uterino (PRCC) é fundamental para que ocorra o decrésci mo do sofrimento desnecessári o experimentado por essas mul heres. Este trabalho aborda questões essenci ais para revital izar o PRCC, tal como proposto pela regulamentação oficial no México. Um marco teórico para institucionali zação do PRCC é del ineado, seguindo-se a apresentação de estratégias, vi sando fortalecer seu desempenho por meio de medi das organizacionais capazes de assegurar a qualidade da assistência prestada. O trabal ho focaliza as atividades segui ntes: 1) melhora da cobertura; 2) implementação no control e de quali dade da obten ção de amostras para exame; 3) mel horia na quali dade de interpretação do exame de Papani colau; 4) garantia de tratamento na presença de anomalias detectadas; 5) melhoria do segui mento; 6) desenvolvimento de medi das de controle da quali dade e 7) desenvolvimento de sistemas de monitoramento edeinformação em vigi lância epi demiológica. Palavras-chave Neoplasias do Colo Uterino; Diagnóstico; Papillomavírus; Controle deQualidade 


\section{Introduction}

New measures have been taken in Mexico to improve the effectiveness of the National Cervical Cancer Screening Program (CCSP), as stated in the recently updated Official Mexican Norm for Detection, Diagnosis and Treatment of Cervical Cancer (Secretaría de Salud, 1997). Following this initiative, the different Mexican health care systems, particularly public and social security health care systems have been working to reorganize their institutional CCSP policies holding close to the revised new official norm. This trend has fueled the process of planning and restructuring specific facilities to run the program in the most efficient way.

The Mexican Social Security Institute (IMSS), which is the biggest health care institution in Mexico, has been reordering its institutional program. This does not mean to design a program with new objectives or specific goals but to reorganize activities and optimally redistribute available resources. The ultimate goal is to run a high qual ity cervical cancer-screening program. To achieve this goal, several field trials have been developed. An example of this effort is an ongoing CCSP field trial, which is taking place in the Mexican State of Morelos (Salmerón-Castro et al., 1997). This study is carefully evaluating concrete alternatives to guarantee the program's efficiency, and to demonstrate the feasibility of the working procedures established in the new Official Norm. In addition, this study is evaluating different alternatives to improve the program through promoting quality assurance strategies.

Quality assurance aims to maintain minimum standards while encouraging the continued striving for excellence. To establish a quality assurance system within a CCSP, it is essential to clearly set a series of criteria and quality standards for every step involved in the program. The process of quality assurance must ensure that quality systems are in place and a set of standards is met (Herbert, 1995a; Salmerón-Castro et al., 1996).

Taking advantage of the cervical screening international recommendations and according to the preliminary experience gained at the I MSS field trial, our aim is to propose a set of standards and to outline an overall quality framework. Within a general administrative organization of a health care system, it is possible to institutionalize a set of CCSP standards. In this paper, we are proposing a set of strategies and techniques to strengthen, maintain, and monitor achievements of the CCSP. The underlying assumptions are that these stan- dards can be fulfilled by any CCSP run by an organized health care system.

\section{General framework for} institutionalizing CCSP

Considering the suggestions and managing recommendations stated by international consensus among countries with well-established CCSP (Coleman et al., 1993; Salmerón-Castro et al., 1997; Parkin \& Moss, 1998), initiative launched by the Mexican Government through the official norm (Secretaría de Sal ud, 1997), it is ruling out several strategies. At first, the aim is to facilitate a close cervical cancer epidemiological surveillance and to ease the long term monitoring of the CCSP activities. The national program recommends to subdivide or decentralize the operative organization in regions or well-defined catchment areas within the area of influence of each health care institution. These regions should preferentially cover no more than 250,000 women at risk for optimal administrative efficiency (Laara et al., 1987).

Each region should count with a comprehensive register the target population that should include all women with active sexual life or aged 25-65 years. This register should also provide data on geographical and age distribution for monitoring the regional CCSP impact (Herbert, 1995b).

As the updated Official Norm establishes, every health care center within each catchment area, must have a strictly reserved area for cervical smear taking. Moreover, each region must rely on a single Cytology Reading Center as part of a pathology laboratory, as well as a Colposcopy Center to attend women with abnormal Pap smear results (Salmerón-Castro et al., 1997; Secretaría de Salud, 1997).

\section{Screening recruitment and coverage}

To effectively decrease the incidence of invasive cervical cancer, all women aged 25-65 years must be examined at least once every three years and the program's overall coverage should be over $85 \%$ of the target population (Herbert, 1995b).

Coverage and compliance are fundamentals to ensure a reliable and efficient CCSP. All personnel involved in the program delivery should be trained to a high standard. Clinical staff and paramedical personnel must know the general administrative framework of the program and should be able to provide ade- 
quate information about screening procedures to the target population. Health care providers should promote and stimulate the program's utilization by means of individual counseling and community health promotion activities. Specific strategies should exist to encourage family physi cians to improve recruitment, such as training courses, use of special guidelines for cervical screening, as well as clinical records labeling as a way of reminding the clinicians about CCSP recruitment (Herbert, 1995b; Salmerón-Castro et al., 1997).

Apart from the medical referral efforts, campaigns to sensitize the population must exist on a regular bases to increase the awareness among the target population about the benefits of participating in cervical cancer screening activities. Alternatives addressed directly to potential users must be established such as promotional posters, seminars and mass media communications. To increase compliance, the population should gain a basic understanding of the nature of cervical cancer, the aim of screening, where it is available, how the procedure is performed, what is the meaning of results and the potential treatment alternatives. Community participation in rural areas in all phases of the program is essential in generating community acceptance (Dignan et al., 1996; Hodge et al., 1996; Matsunaga et al., 1996; Megevand et al., 1996). Implementing selective dissemination of information about the cervical cancer screening program in different contexts (rural, urban, suburban and border areas) may be needed. Alternative strategies for recruiting can be used for specifically targeting women with persistent non-responses to regular reporting procedures, such as personally addressed mailed invitations (Coleman et al., 1993; Crombie et al., 1994; Herbert, 1995b), or home visitations by social workers.

For a long time, Pap smear testing has been considered the gold standard procedure for cervical cancer screening. However, during the last few years, sensitive procedures for cervical cancer screening have been tested. Furthermore, acceptable procedures for sample collection other than the pelvic examination, which is required for Pap smears have been under scrutiny.

The well-documented role of HPV infection in cervical cancer causality has given new insights on the development of better technologies for improving sensitivity on cervical screening procedures. HPV testing has gained increased attention as an alternative or as an adjunct for identifying pre-invasive and invasive cancer. A careful evaluation of these new technologies should provide highly valuable information to improve the CSP effectiveness.

\section{Q uality control of cervical} smear taking centers

Each medical unit must count on well-trained personnel in charge of smear taking. These personnel should be responsible for Pap smear sample collection and gathering general information for registration purposes. Smear takers must periodically complete training curses to guarantee the quality of these procedures. Standardized protocols for cervical sampling, slides preparation, material identification and safety transportation should be further developed.

A permanent and systematic quality evaluation of Pap smear sample collection procedures must exist. Periodic reports (preferable monthly) of smear quality should be issued by the Cytology Center; these reports must include information on indicators of transformation zone sampling and sample conditions (Lundberg, 1989; Chu et al., 1991). This information should help to identify centers with high rates of low quality smears, as well as personnel responsible for these deviations. In this way, it would be possible to address training procedures and qual ity assurance strategies to be overcome through a problem-solving approach to the deficiencies.

Table 1 is showing the main objectives and quality standards regarding Pap smear-collection. Abnormal or unsatisfactory smears can occur in the presence of invasive carcinoma; thus, a clinical suspicion of invasive cancer should overrule a regular cytological report. Patients with these findings should be referred directly to the Colposcopy Center.

\section{Quality control of cytology-reading center}

The Cytology Reading Center must concentrate all smears from the catchment area. In order to guarantee that technicians could be exposed to a reasonable amount of abnormal smears. The center should read 35,000 samples annually as a minimum and each technician should read 40 to 60 smears a day.

Each center must have a responsible pathologist in charge of quality control, permanent supervision of a technician's performance and a system for solving interpretation doubts. In 
Table 1

Pap smears' collection quality assurance activities.

\begin{tabular}{lll}
\hline Objective & Procedure & Targ ets \\
\hline $\begin{array}{l}\text { Warrant the quality of } \\
\text { the sample }\end{array}$ & Training courses & $\begin{array}{l}100 \% \text { of smear takers must credit } \\
\text { training courses every year }\end{array}$ \\
\hline Keeping and improving skills & $\begin{array}{l}\text { Keep a minimal of smears taken } \\
\text { every day }\end{array}$ & $>8$ daily smears by each smear taker \\
\hline Optimal conditions of samples & $\begin{array}{l}\text { Supervision and monitoring of the } \\
\text { quality of the samples }\end{array}$ & $\begin{array}{l}100 \% \text { presence of end ocervical } \\
\text { or metaplastic cells }\end{array}$ \\
\hline $\begin{array}{l}\text { Assuring transformation } \\
\text { Zone sampling }\end{array}$ & $\begin{array}{l}\text { Maintaining smear conditions } \\
\text { Counting for excessive blood cells } \\
\text { (leukocytes or erythrocytes) } \\
\text { badly distributed } \\
\text { badly fixed }\end{array}$ & $<20$ \\
\hline $\begin{array}{l}\text { Users' satisfaction and perception } \\
\text { about quality of care }\end{array}$ & Routine users' interviewing & $<3 \%$ \\
\hline
\end{tabular}

Table 2

Classification of cytological diagnosis.

\begin{tabular}{ll}
\hline NIC (WHO) & BETHESDA \\
\hline Normal & Normal \\
Condiloma & Atypical glandular cells of undetermined significance (AGUS) \\
NIC I & Atypical squamous cells of undetermined significance (ASCUS) \\
NIC II & Low-grade squamous intraepithelial lesion (LGSIL) \\
NIC III & High-grade squamous intraepithelial lesion (HGSIL) \\
Microinvasive CA & Adenocarcinoma \\
Invasive CA & Invasive CA \\
\hline
\end{tabular}

addition, periodic training courses should be provided to update and increase diagnosis accuracy.

According to well-defined Pap smears examination procedures a cytological diagnosis should be stated following internationally accepted classification. Table 2 is showing two commonly used diagnosis criteria. Internal quality control procedures, including interobserver agreement, false positive and false negative rates, should be assessed on a regular bases: a technician's double reading and permanent reexamination of all positive smears and part of negatives should be performed by a responsible pathologist. The Center must count on an external quality control of smear readings through routine assessment of accuracy diagnose performance by means of peri- odic external evaluation. The set of criteria and standards that we propose for quality control of the Cytology Center are presented in Table 3.

All abnormal smears should be kept in the laboratory as reference material for teaching and training purposes, as well as 2-5\% of normal smears for long term cytological diagnosis quality control procedures. Carrying out a double screening procedure is desirable to improve quality control systems and screening accuracy. Automated reading equipment could be used (e.g. PAPNET or NeoPath) for conventional Pap smear samples or special monolayer preparations to facilitate electronic image analysis (Wied, 1993; Birdsong, 1996).

If CCSP were using cytomorphological criteria, it could be more effective if the screening were to include objective individual risk factors 
Criteria and standards of quality control for the regional cytology center.

\begin{tabular}{|c|c|c|}
\hline Objective & Procedure & Targets \\
\hline \multirow[t]{3}{*}{$\begin{array}{l}\text { Warrant the productivity and } \\
\text { smears' reading }\end{array}$} & $\begin{array}{l}\text { Used/checked for the annual } \\
\text { sreening by: }\end{array}$ & \\
\hline & 1) Center & $<35000$ smears a year \\
\hline & 2) Technicians & $>40$ smears/day/technician \\
\hline $\begin{array}{l}\text { Warrantee of the quality } \\
\text { cytological diagnosis }\end{array}$ & $\begin{array}{l}\text { Sensibility of the initial reading in } \\
\text { regard to the final report after a } \\
\text { fast check }\end{array}$ & $>85 \%$ \\
\hline Confirmation citology diagnosis & Re-examination by a cytopathologist & $\begin{array}{l}1 \text { to } 5 \% \text { of normal and all positive } \\
\text { smears }\end{array}$ \\
\hline \multirow[t]{2}{*}{ Timeline for results reporting } & $\begin{array}{l}\text { Women who receive their results } \\
\text { within fo ur weeks after screening }\end{array}$ & $>85 \%$ \\
\hline & $\begin{array}{l}\text { Women who receive their results } \\
\text { within } 8 \text { weeks after screening }\end{array}$ & $>95 \%$ \\
\hline
\end{tabular}

for women with normal cytology, such as a test for high risk of HPV. Previous reports support the view that the interval between successive smears in CC screening can be increased considerably for women with cytomorphologically normal and high-risk HPV-negative cervical smears (Schneider, 1996). Before screening for high risk HPVs can be generally recommended, HPV-testing has to be carefully evaluated in large epidemiological studies (Schneider \& Zahm, 1996).

\section{Follow-up procedures}

Ever catchment area must have a set of specific procedures to ensure follow-up of women with Pap abnormalities. A general guideline for these procedures could be as follows:

1) All women must be informed about their results, within 3-4 weeks after the Pap smear collection. The health providers in charge of sample collection at Pap smear-taking centers should mainly perform this. In addition, family physicians must have these results at the same time to give additional information to the patients.

2) Women with Pap smear abnormalities (atypical squamous cells of undetermined significance (ASCUS); atypical glandular cells of undetermined significance (AGUS); low-grade squamous intraepithelial lesions (LGSIL); highgrade squamous intraepithelial lesions(HGSIL); and invasive cancer, must be referred to the Re- gional Colposcopy Center for further evaluation (Figure 1). Whenever it is possible, with a pre-scheduled appointment specifying date and hour.

3) If after six weeks of Pap smear collection, any woman with an abnormal Pap smear who has not been scheduled for colposcopy would receive a mandatory communique from the Social Worker Department by telephone, telegram or home visit. The aim is to inform them about the need of attending the Colposcopy Center for final diagnosis and/ or receive appropriate treatment.

4) Women who have received their (positive) results but have not attended Colposcopy Clinics (within 6 weeks) have to be contacted and encouraged by the Social Worker Department to attend, and a new appointment date should be offered.

\section{Q uality control for colposcopy centers}

Management of patients with abnormal smear results will depend on the degree of abnormality. A general guideline proposal to manage and follow-up women with abnormal Pap smears is presented in Figure 2.

The colposcopy procedures must be reported in specially designed results-reporting formats. These reports should contain the information on colposcopy findings, treatment provided, and the follow-up recommendations made. At the end of the diagnose and treat- 


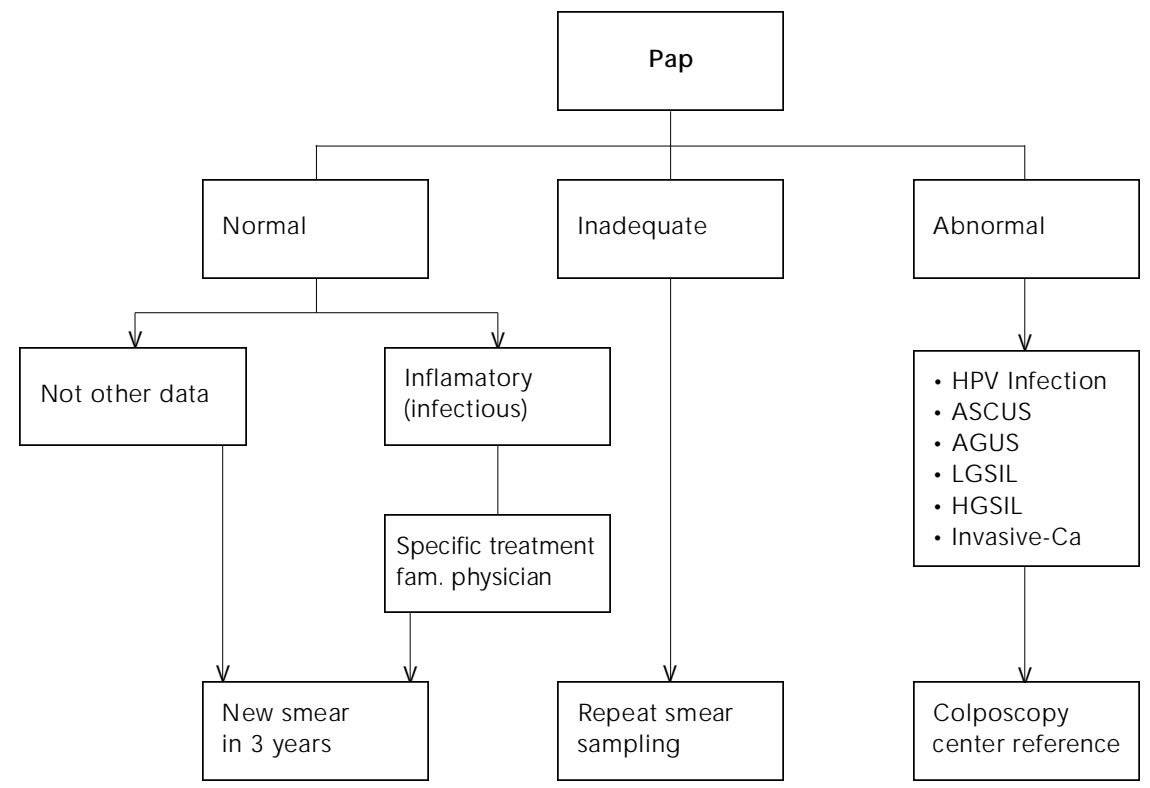

ment procedures all patients must be informed about the results and receive follow-up recommendations. A comprehensive report of diagnostic and/ or performed therapeutic procedures should be provided to the patient's family physician. This will assist the physician in giving additional information to the patient and to further comply with the therapeutic procedures that are needed. Cases referred to gynecology or oncology services should be closely followed to warrantee compliance to the required therapeutic procedures. For noninvasive cancer, combining appropriate followup and outpatient therapy methods such as cryotherapy and the loop electrosurgical excision procedure (LEEP), should be encouraged because of their effectiveness, lack of side effects, simplicity, and low cost (Bishop et al., 1996).

A system to monitor the quality of care at the Colposcopy Center must be established to evaluate the service performance in a permanent way. This must be done through paired evaluations of colposcopy diagnose, managerial evaluations and by established qual ity control indicators (Table 4). The combination of cytology and cervicography can decrease the number of recalls, biopsies, and unnecessary treatments, while reducing costs. Down-stag- ing invasive cancer by visual inspection seems a cost-effective alternative to the cytology in countries with limited health facilities. Other methods such as laser-induced fluorescence, computerized digital imaging colposcopy or computer imaging have a potential to be used for future triaging. However, there is insufficient data available to evaluate the cost-effectiveness of these techniques (Cohen, 1996).

\section{Monitoring and epidemiological} surveillance information system

\section{Register system}

The reading centers should have computer technical personnel in charge of the registering systems. All information should be captured in specialized software to create a reliable Epidemiological Surveillance System.

At the end of each week, a concentrated harvest of PAP results should be sent to each Cervical Screening Center. In this way, it could be possible to inform each woman about her cervical screening results and to set follow-up recommendations. Colposcopy forms containing the main findings should be also registered At the end of the follow-up, the results should 
Posterior handling to cone.

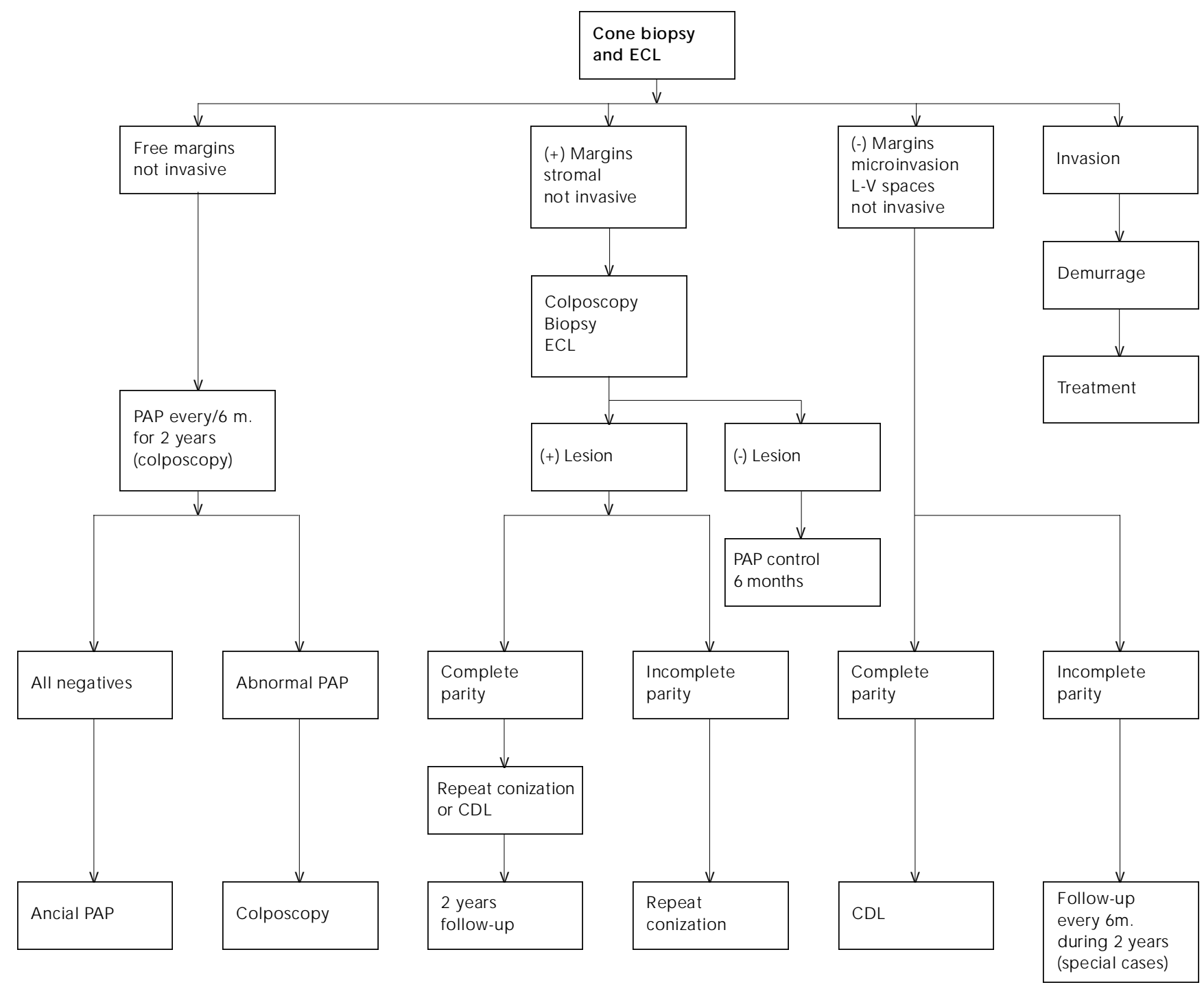

$\mathrm{ECL}=$ endo cervical treatment

$\mathrm{CDL}=$ conization with diathermic loop

be recorded in an independent report and captured. All this data will feed into the Monitoring and Epidemiological Surveillance System (Miller, 1992).

Establishing an automated monitoring system will help supervise specific program procedures and goals: coverage, results-reporting intervals, smears quality, follow-up and treatment compliance.

With the aim of monitoring the CCSP, comprehensive, periodical reports including necessary information to evaluate the program should be generated, to assess specific procedures and its impact over the main components of the program. This will also correct deviations and facilitate constant improvements in the program. A Special Regional Quality Control Committee should carefully evaluate this information.

An automated Cervical Cancer Epidemiological Surveillance System should create aggregated charts of regional cervical cancer behavior, occurrence of pre-invasive lesions, cancer and mortality rates, as well as the use of 
Quality control of dysplasia center target.

Quality control indicators* of dysplasia center performance

1) Occurrence of cervical bleeding after intervention

2) Occurrence of women with cervical estenosis after intervention

3) Presence of the escamocolumnar junction after intervention

4) Persistence of positive marg ins after intervention (cryotherapy, lo op diathermy)

5) Persistence of cervical neoplasia after intervention

6) Determination of the specimen's hystology quality

7) Determination of the specimen's cytology quality taken.

8) Correlation studies of cyto-hystology-colposcopy.

* Indicators and benchmarking should be tailored according to the characteristics of the dysplasia center.

\section{Table 5}

Cervical cancer screening regional epidemiological surveillance (outputs and outcome indicators).

\begin{tabular}{|c|c|}
\hline Output indicators & Outcome and impact indicators \\
\hline Use of health services (every year) & Morbidity - mortality \\
\hline a) Cytologies & Anual (incidence rates) \\
\hline $\begin{array}{l}\text { b) Colposcopy - central } \\
\text { NIC treatments (loop diathermy, conization) }\end{array}$ & $\begin{array}{l}\text { Preceding lesions } \\
\text { In situ cancer } \\
\text { Invasive cancer }\end{array}$ \\
\hline $\begin{array}{l}\text { c) Referrals to oncology-gynecological services (hysterectomy, } \\
\text { surgical treatment, radiotherapy \&/or quimotherapy }\end{array}$ & $\begin{array}{l}\text { Mortality due to cervical cancer } \\
\text { Number of averted cases of invasive cancer } \\
\text { Number of averted deaths }\end{array}$ \\
\hline $\begin{array}{l}\text { d) Bed/days due to cervical cancer care (second } \\
\text { and third level) }\end{array}$ & QALYs and DALYs gained after treatment \\
\hline
\end{tabular}

health services due to cervical cancer in each region. This information should allow the assessment of medium and long term cervical cancer behavior at regional levels. Available information of preinvasive-lesions incidence as well as cervical cancer and mortality rates should permit an analysis of the cost-effectiveness of the screening program: costs per life year gained or cancer free life year gained (Raffle, 1996).

Table 5 is highlighting main output and outcome indicators that could be used to measure impact and effectiveness of the CCSP.

\section{Comment}

Advocacy to reordering current policies to deliver appropriate cervical cancer screening activities should be supported by increasing investment both in human and physical resources. Unfair competition of resourcesamong programs and cost-cutting policies has worsened health status of women even in developed countries (Magrath \& Litvak, 1993; Harrison \& Seppala, 1997). Thus, developing stringent strategies and quality-related activities could obtain sound results to decrease the problem of delivering services for invasive cervical cancer. 
BIRDSONG, G., 1996. Automated screening of cervical cytology specimens. Human Pathology, 27: 468-481.

BISHOP, A.; SHERRIS, J.; TSU, V. D. \& KILBOURNEBROOK, M., 1996. Cervical dysplasia treatment: Key issues for developing countries. Bulletin of the Panamerican Health Organization, 30:378386.

CHU, K. C.; KRAMER, B. \& SM ART, C., 1991. Analysis of the role of cancer prevention and control measures in reducing cancer mortality. Journal of the National Cancer Institute, 83:1636-1643.

COHEN, M. M., 1996. Why is there no progress against cervical cancer? Canadian Medical Association Journal, 154:1867-1869.

COLEMAN, D.; DAY, N.; DOUGLAS, G.; FARMERY, E.; LYNGE, E.; PHILLIP, J. \& SEGNAN, N., 1993. European guidelines for quality assurance in cervical cancer screening. Europe against cancer programme. European Journal of Cancer, 29A(Sup. 4): S1-S38.

CROMBIE, I. K.; ORBELL, S.; JOHNSTON, G.; ALISTAIR, J. R. \& KENICER, M., 1994. Cervical screening: the optimum visit plan for contacting users and non-users in Scotland. Journal of Epidemiology and Community Health, 48:586-589.

DIGNAN, M.; MICHIELUTTE, R.; BLINSON, K.; WELLS, H. B.; CASE, L. D.; SHARP, P.; DAVIS, S.; KONEN, J. \& MCQUELLON, R. P., 1996. Effectiveness of health education to increase screening for cervical cancer among eastern-band cherokee indian women in North Carolina. Journal of the National Cancer Institute, 88:1670-1676.

HARRISON, K. \& SEPPALA, M., 1997. Obstetrics and gynaecology: Women and market forces. Lancet, 350(Sup. III):16.

HERBERT, A., 1995a. Achievable Standards, Benchmarks for Reporting \& Criteria for Evaluating Cervical Cytopathology. NHSCSP publication oo 1.

HERBERT, A., 1995b. Achievable standards, benchmarks for reporting, criteria for evaluating cervical cytopathology. Cytopathology, 6(Sup. 2): 7-26.

HODGE, F. S.; FREDERICKS, L. \& RODRIGUEZ, B., 1996. American Indian women's talking circle: a cervical cancer screening and prevention project. Cancer, 78(Sup. 7):1592-1597.

LAARA, E.; DAY, N. E. \& HAKAMA, M., 1987. Trends in mortality from cervical cancer in Nordic countries: association with organized screening programmes. Lancet:1247-1249.

LUNDBERG, G., 1989. Quality assurance in cervical cytology: the papanicolau smear. JAMA, 262: 1672-1679.
MAGRATH, I. \& LITVAK, J., 1993. Cancer in developing countries: opportunity and challenge. Journal of the Nati onal Cancer Institute, 85:862-874.

MATSUNAGA, D. S.; ENOS, R.; GOTAY, C. C.; BANNER, R. O.; CAMBRA, H.; HAMMOND, O. W.; HEDLUND, N.; ILABAN, E. K.; ISSELL, B. F. \& TSARK, J. A., 1996. Participatory research in a Native Hawaiian community: The Waianae Cancer Research Project. Cancer, 78(Sup.):1582-1586.

MEGEVAND, E.; VAN-WYK, W.; KNIGHT, B. \& BLOCH, B., 1996. Can cervical cancer be prevented by a see, screen, and treat program? A pilot study. American Journal of Obstetrics and Gynecology, 174:923-928.

MILLER, A. B., 1992. Cervical Cancer Screening Programmes: Managerial Guidelines. Geneva:World Health Organization.

PARKIN, D. M. \& MOSS, S. M., 1998. An evaluation of screening policies for cervical cancer in England and Wales using a computer simulation model. Journal of Epidemiology and Community Health, 409:143-153.

RAFFLE, A., 1996. The economics of screening. Cytopathology, 7:227-230.

SALMERON-CASTRO, J.; LAZCANO-PONCE, E. C. \& HERNANDEZ-AVILA, M., 1996. Programa de detección oportuna de cáncer en instituciones de seguridad social. Una al ternativa organizacional. Cancerología, 42:159-165.

SALMERON-CASTRO, J.; PEREZ-CUEVAS, R.; REYESMORALES, H.;TORRES-MEJIA, G. \&TORRES-TORIJA, I., 1997. Evaluación de una intervención comunitaria para el control del cáncer cervical en la delegación Morelos del Instituto Mexicano del Seguro Social. Unidad de Investigación Epidemiológica y en Servicios de Salud CMN Siglo XXI. Documento interno.

SCHNEIDER, A., 1996. Virology screening. European Journal of Obstetrics, Gynecology, and ReproductiveBiology, 65:61-63.

SCHNEIDER, A. \& ZAHM, D. M., 1996. New adjunctive methods for cervical cancer screening. Obstetrics and Gynecology Clininics of North America, 23:657-673.

SECRETARIA DE SALUD, 1997. Proyecto de modificación a la Norma Oficial Mexicana NOM-014SSA-1994, para la prevención, tratami ento y control del cáncer del cuello del útero y mamario en la atención primaria. Diario Oficial de la Federación. Tomo DXXVII no 1 agosto. M éxico, D.F.: Secretaría de Salud.

WIED, G. L., 1993. Industrial developments in automated cytology as submitted by their developers. Analytical and Quantitative Cytology and Histology, 15:358-370. 